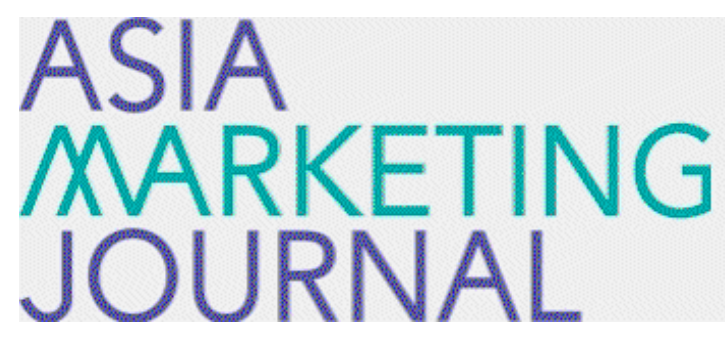

ASIA MARKETING JOURNAL

Volume 15 | Issue 1

Article 6

4-30-2013

\title{
Empirical research on the influence of spatial competition in the distribution industry on consumer behaviors in South Korea
}

Su Dong Lee

Woo Hyoung Kim

Follow this and additional works at: https://amj.kma.re.kr/journal

Part of the Marketing Commons

\section{Recommended Citation}

Lee, Su Dong and Kim, Woo Hyoung (2013) "Empirical research on the influence of spatial competition in the distribution industry on consumer behaviors in South Korea," Asia Marketing Journal: Vol. 15 : Iss. 1 , Article 6.

Available at: https://doi.org/10.53728/2765-6500.1512

This Article is brought to you for free and open access by Asia Marketing Journal. It has been accepted for inclusion in Asia Marketing Journal by an authorized editor of Asia Marketing Journal. 


\title{
Empirical research on the influence of spatial competition in the distribution industry on consumer behaviors in South Korea*
}

\author{
Sudong Lee** \\ Woohyoung Kim***
}

When Korea's retail industry was liberalized, new store formats such as large discount stores and Super Supermarket(SSMs) have grown. New types of business have borne significant influence on traditional market. Traditional markets have been in gradual decline since they fail to meet to consumer's purchasing behavior. The South Korean government has been making sustained efforts to revitalize the modernization of traditional markets since 2004. This research is conducted to analyze how changes in the distribution of different types of distributors influence the consumer's purchasing behaviors depending on the changes in the market environment. The purpose of this research is to present a policy to invigorate consumer-oriented traditional markets by analyzing the consumption behavior among major retail channels at a point when competition among retail channels is becoming intensified. In order to examine the effect of the spatial competitive landscape among major retail channels on consumption behavior, an empirical analysis was conducted with 613 consumers in 6 cities nationwide, using the multiple regression model. This research identified three main areas of factors. The analysis result indicates that the physical factor (time required to go to the traditional market), socioeconomic factors (the number of vehicles owned and average monthly income), and competitive factors (intensity of competition in spatial locations and average monthly spending in supermarkets) have significant influence on consumption patterns of consumers. The findings present that the Korean government should go ahead with policies aimed to revitalize traditional markets, keeping in mind the factors that influence the consumption patterns of customers based on these results. We propose that the policy supporting traditional markets need to be a customized-strategy. considering traditional market's characteristic.

Key words: multi-regression analysis, consumer behavior, large discount store, Super Supermarket (SSM), retail industry

\footnotetext{
* This research is a revision, with supplements, of the content of "A Study on the analysis of spatial competition and policy implication among traditional market. large discount store, and SSM" by Agency for Traditional Market Administration, Small and Medium Business Administration (2011).

** Professor, Business Administration, Kookmin University, Korea(kulsd@kookmin,ac.kr)

*** Corresponding Author, Senior Researcher. Agency for Traditional Market Administration. Small Medium and Business Administration, Korea(kimwh@sijang.or.kr)
} 


\section{Introduction}

Markets are the birthplaces of cities. In some cases, markets began as crossroads where travelers would barter their goods and chattel for products. They were catalysts in the development of hamlets into villages, villages into towns, and towns into cities (Department for Communities and Local Government of the UK, 2010). The conventional distribution of business districts has been negatively influenced by the globalization phenomenon: the number of large discount stores and supermarkets is increasing explosively, and this is playing a key role in the distribution industry today. The globalization of retailers' supply strategies has stimulated the competitiveness of retailers in local markets, boosting national market concentration as the basis of the retailer's power (Clarke, 2000). The Korean government opened the distribution market in 1996. Since then, a number of foreign distribution companies have entered the Korean market, and the number of large discount stores, supermarkets, and online shopping avenues has grown fast. This new wave in the distribution market threatens the sustainability of distributors and retailers in traditional markets. Acoording to SMBA (2010), the Korean government has provided financial support of USD 19 billion for 777 traditional markets to renovate facilities and improve market quality. However, sales in the traditional market continue to decrease despite governmental support and efforts, whereas the sales of competitors such as large discount stores, supermarkets, and SSMs continue to increase. Since this new wave of large discount stores and supermarkets in the Korean distribution market, competition among retailers has intensified, and business districts of traditional markets have been downscaled. Similarly, competitors have grown in the Korean traditional market. For this reason, there have been many changes in the spatial structures of retailers in terms of distribution and business districts (Kim and Hallsworth, 2013). In particular, there have been many changes in the purchasing patterns of consumers as their income levels and lifestyles have improved.

As large discount stores and SSMs (Super Supermarket), operated by conglomerates, started to aggressively expand their marketing network in the 2000s, the competitiveness of traditional markets and shopping districts began to decline. The stronger the competitiveness of large discount stores and SSMs became, the weaker the competitiveness of traditional markets and shopping districts became. Recently, large distribution companies are opening multiple shopping complexes, which bring shopping, culture, and leisure together, one after another. Since large discount stores and department stores are inside the multiple shopping complexes, the departure of customers from surrounding traditional markets and shopping districts is expected to accelerate. As a result, the commercial sphere 
of new distribution companies, such as large discount stores and SSMs, is gradually expanding, and the dominance of conglomerates in the distribution market is deepening. As the indiscriminate expansion of new retail channels, such as large discount stores and SSMs consistently threatened the livelihood of small and medium-sized business owners, the government established a Traditional Market Preservation Zone in 2011, restricting the entry of large distribution stores operated by conglomerates within $1 \mathrm{~km}$ from the boundary of traditional markets. The National Assembly and the government carried the scheme a step further when the government amended the 'SSM Restriction Act' in January 2013, restricting the opening hours (from midnight to 10 A.M.) of and enforcing mandatory holidays (twice a month on Sundays or public holidays) on distribution companies operated by conglomerates. Kim and Hallsworth (2013) alluded that a new wave of large discount stores and SSMs has led to a restructuring in Korean distribution market. They provided an empirical case study which shows the effect of government-led regulations to restrict retail conglomerates for protecting and revitalizing small and medium-sized business owners in Korea.

For that reason, we attempt to analyze how changes in the distribution of different types of distributors (large discount stores, supermarkets, and traditional markets) influence the consumer's purchasing behaviors depending on the changes in the market environment. The purpose of this research is to offer a framework to support small and medium-sized business owners by analyzing diverse variables such as competitive factors, psychological factors, and socioeconomic factors. The consumption behavior study was conducted by selecting 6 regions out of the 52 regions with at least 3 traditional markets in the metropolitan area, and examining and analyzing the consumption behavior of the major players. Using multiple regression analysis, we will also conduct an empirical analysis of the influence of spatial competition among the traditional markets, large discount stores, and SSMs on consumer consumption behavior in the traditional markets, from the aspect of location. The purpose was to present a future direction for a governmental policy to support small and medium-sized business owners.

\section{Literature review}

\subsection{Traditional market}

Belshaw (1965) defined a market as a place that has social, economic, cultural, and other objects where the people who will buy these objects come to decide on their prices and pay them. The notion of traditional markets is defined differently depending on the historical flow, and the definition can be classified into legal 
and functional ones. First, the legal definition stipulates, under a special act for the traditional markets, that a traditional market is a large-scale store or people-driven market where there are old commercial infrastructures that need to be mended or repaired or a place whose management needs improvement or business needs modernization because it has a weak distribution function. From the functional perspective, Kim et al., (2000), in accordance with the concept of a market under "the Special Act for Reorganization and Stabilization of Small and Medium-Sized Enterprises," defined a traditional market as one that needs redevelopment or modernization, as its facilities have become decrepit because it was opened a long time ago. The domestic traditional markets, based on their various functions and roles, have grown in tandem with the national development. Historically, the traditional markets had not only the function to offer agricultural/livestock products, necessities, and industrial products for wholesale and retail distribution but also a kind of political function to spread culture, strengthen the community, and create a communal space for the people (Kim, 2005).

\subsection{Consumer behavior}

First, we need to define what consumers are. In many studies, the consumer is defined as a person (i.e., a final consumer) who purchases goods or services to consume. Schiffman and
Kanuk (1987) defined consumer behavior as behavior that consumers present in searching for, purchasing, using, evaluating, and disposing of products and ideas that satisfy their needs. Consumption behaviors have been defined in many different ways by researchers and scholars. Bruck (1967) stated that consumption behaviors include all the activities in the course of selecting and using goods and services. Engle and Blackwell (1982) defined consumption as an individual action to obtain and use economic goods and services, including the decision-making process before taking action. In relation to consumer behavior. Tauber (1972) explained shopping motives as part of individual motives and social motives as follows: Individual motives include role playing, diversion, self-gratification, learning, and physical activity: and social motives include social experience, communication, peer group attraction, status, and pursuit of authority. Runyon (1980) also demonstrated that consumer behavior embroils planning, purchasing, and using behaviors related to the purchase of goods and services. Consumer behaviors can be defined as the consumption style of consumers during purchasing activities. Consumer behaviors are behavior patterns that drive consumers to shopping facilities, and are a basic element of consumption patterns. 


\subsection{Previous studies}

Many studies have been conducted to analyze how competition among distributors influences consumers consumption behaviors in diverse areas, including geographical information studies, distribution studies, and economics. A number of studies have analyzed the influence of new types of markets (large discount stores, supermarkets, online shopping, etc.) on consumption behaviors. Specifically, many researchers have studied how online shopping influences consumer behaviors (Koufaris, 2002: Degeratu, 2000: Park et al.. 2007). Liang and Huang (1998)'s study have shown that different products have different levels of customer acceptance through online shopping. Mahmood et al. (2004) analyzed the influence of online shopping on consumer behaviors by studying consumers in 26 nations: they asserted that trust and economic conditions have made significantly positive contributions to consumption behavior. Sheri et al., (2003) conducted a research on the comparing online and non-online shoppers. They found that the educational needs of consumers differ based on their precious experience with online shopping. In addition, many studies have investigated how consumer behaviors influence the use of large discount stores (Kim and Jin, 2001: Singh, 2006: Kim, 2008). Kim and Jin (2001) analyzed the differences between Korean consumers using domestic discount stores and those using multi- national discount stores. According to their results, there were obvious differences in store image perception and shoppers' internal orientations. In addition, many researchers analyzed the influence of online shopping, large discount stores, and supermarkets on consumer behaviors (Andrews, 2004: Hernandez, 2006).

There is also research related to the competition among channels in the retail industry. Farina et.al., (2005) concluded that large supermarket chains would eradicate traditional stores and smaller supermarkets as well, because of price competition. Cleeren et.al., (2010) used an empirical entry model was study competition between discount grocery stores and traditional supermarkets in Germany. They emphasized that supermarkets are engaged in ferocious competition. They also found strong evidence of intra-format competition between discounters in Germany. There are many studies on the key players in the distribution market (online shopping, large discount stores, supermarkets, etc.), whereas studies on the traditional markets' influence on consumer behaviors are relatively few. Most studies on the traditional markets' influence on consumer behaviors relate to the unique characteristics of these traditional markets, such as their specialized products, traditional culture, festivals, etc. There is an assertion that the consumers of today visit traditional markets because of their atmosphere and products (Nobel, Griffith, and Adjei, 2006: Lee et al., 2008). Brennan and Lundsten (2000) also 
asserted that the reason the consumers of today visit the traditional markets rather than the modern large-scale retail stores is because they can purchase unique atmosphere. Kim and Kim (2012) conducted an empirical analysis to revive regional economies. They illustrated that cultural tourism business in traditional distribution market is a valuable policy for a developing country in terms of regional development. Ibrahim and Leng (2003) insisted that traditional markets give opportunities to retailers and customers to trade products. They especially stressed that traditional markets vitalize the local economy by attracting domestic and foreign shopping tourists. They also stressed that traditional markets have an important role that maintains the community by providing leisure and cultural spaces to residents in the area. Some studies were carried out to identify the particular factors of traditional markets that influence consumer behaviors. Kim (2011) asserted that the physical factors of traditional markets have the greatest influence on consumer behaviors. Policies to improve the accessibility and convenience of traditional markets are urgently needed to revitalize these markets. Goldman and Hino (2005) also demonstrated that product freshness, cultural factors, accessibility, and other factors have influence a consumer's choice of supermarket versus traditional retail shop use.

\section{Methods}

\subsection{Purpose of Analysis}

Despite the fact that the location factor plays a critical role for success in the retail industry, there has been an absolute lack of studies which approached the issue from the location aspect of large distribution companies, such as large discount stores, SSMs, etc., for the invigoration of traditional markets. In particular. there are wide variations in the degree of competition among major retail channels by region, resulting in a more fierce spatial competition between traditional markets and large discount stores, SSMs, etc. in heavily populated metropolitan areas in comparison to small and medium-sized cities.

This chapter will analyze the effect of spatial competition between traditional markets and large discount stores, SSMs, etc. on the consumption behavior of traditional markets from the location aspect. It is evident that examining the spatial aspect, that is, location status and characteristics of change in conditions, of retail channels is a cornerstone for preparing a strategy to invigorate traditional markets. Therefore, this chapter aims to figure out the actual consumption situation at traditional markets and present various countermeasures which are necessary for invigorating traditional markets, by 
analyzing not only the effect of spatial competition among retail channels on the consumption behavior of consumers at traditional markets but also the effect of psychological, socioeconomic, and physical factors on the consumption behavior of consumers at traditional markets.

\subsection{Selection of sample areas}

In this chapter, we attempt to analyze how spatial competition (locations) among traditional markets, large discount stores, and SSMs influences consumption behavior. Spatial competition among traditional markets, large discount stores, and SSMs is of various types. In this research, competition is classified into three categories: "strong," "average," and "weak." The purpose of this classification is to establish a policy for the revitalization of traditional markets by providing significant strategies based on the clearly defined characteristics of the competition. We chose metropolitan areas as sample regions for this research, for the following reasons. First, metropolitan areas that have most intense spatial competition among traditional markets, large discount stores, and SSMs are the most suitable samples for our analysis. Second, metropolitan areas show clear spatial competition among traditional markets, large discount stores, and SSMs.

In this analysis, the scope of the investigation of business districts according to types of re- tailers is set at $800 \mathrm{~m}$ for SSM and $3 \mathrm{~km}$ for large discount stores. The process of selecting sample areas comprises three steps. Step 1: Investigate areas that have a certain number of traditional markets by "si" (city), "kun" (county), and "gu" (borough). We have selected "si," "kun," "and "gu" that have more than three traditional markets: as a result, 52 areas in the metropolitan area have been selected. Step 2: Define the types (strong, average, and weak) of spatial competition. We have examined spatial competition between traditional markets and large discount stores and between traditional markets and SSMs. Accordingly, two types of spatial competition have been identified. The population in the business districts of the traditional markets matches the population in the business districts of the large discount stores in areas where there is "strong" spatial competition among traditional markets, large discount stores, and SSMs.

Additionally, in these areas, the population in the business districts of SSMs includes over $70 \%$ of the population in the business districts of the traditional markets. In areas where there is "average" spatial competition, 70 99\% of the population in the business districts of the traditional markets is included in the population in the business districts of the large discount stores. In these areas, the population in the business districts of SSMs includes $40 \sim 70 \%$ of the population in the business districts of the traditional markets. Lastly, in areas where there 
is "weak" spatial competition, less than $70 \%$ of the population in the business districts of the traditional markets is included in the population in the business districts of the large discount stores. In these areas, the population in the business districts of SSM includes less than $40 \%$ of the population in the business districts of the traditional markets. The total number of areas selected through Step 2 is 19 " $s i$ " (city), "kun" (county), and "gu" (borough), which can be broken down into 8 areas with "strong" competition, 5 areas with "average" competition, and 6 areas with "weak" competition. Step 3: Select sample areas. Although it would be ideal to analyze all the 19 areas selected in Step 2 , considering the limited budget, we have selected sample areas. For geographic distribution within the metropolitan area, we have selected six areas, as follows: Gangseo-gu (Seoul), Gwan'ak-gu (Seoul), Uijeongbu-si (Gyeonggi-do), Dongducheon-si (Gyeonggi-do), Seo-gu (Incheon), and Ganghwa-kun (Incheon).

\subsection{Variables}

We applied variables to analyze how spatial competition among traditional markets, large discount stores, and SSMs influences consumption behaviors in traditional markets. These variables were selected by referring to precedent studies and literature surveys. In this research, "average monthly spending in traditional markets" was applied as a dependent. Studies have frequently been conducted on determinants in selecting retailers based on consumption behaviors, and the key determinants are reported to be quality of service, reasonable price, products, display, convenience, atmosphere, image, etc. (Bucklin, 1996: Blackwell, Miniard, and Engel, 2001: Levy and Weitz, 2001: Chowdhury, Reardon, and Srivastava, 1998). In addition, the location (Bell, Ho, and Tang, 1998) and types of retailers in a business district (Gripsrud and Horverak, 1998) have been shown to have a direct influence on consumer behaviors. The objective of this analysis to determine how the spatial competition between large discount stores and SSMs influences the consumption behaviors of consumers in traditional markets. Independent variables used in this analysis are classified into psychological factors, physical factors, socioeconomic factors, and competitive factors. In general, variables that are used in analyzing why consumers use retailers (including traditional markets) are psychological factors. Variables that are related to the satisfaction of consumers can be set up separately. In this research. product quality, variety of products, transportation convenience, parking convenience, atmosphere, and kindness of merchants have been chosen. For physical factors, we can use the distance or the time between the traditional market and where the consumer lives. In cases where a physical factor measures spatial accessibility, the time taken to travel from where consumers live to the traditional market 
can be a more accurate standard than the distance between these two points. In this research, we used the average time required by a consumer to visit a traditional market. For socioeconomic factors, we applied length of residence, number of cars owned, and average monthly income. In the precedent, it was proven that the number of cars owned and average monthly income have a direct influence on consumption behaviors. Therefore, it is necessary to control these variables by including them as independent variables. Length of residence, as a socioeconomic factor, is also included as an independent variable. This is because there can be a close correlation between length of residence and the consumption behaviors of consumers in traditional markets, as these traditional markets are typical community-centered retailers.

The hypothesis on how the independent variables in this analysis influence the consumption behaviors of consumers in traditional markets is as follows. It is predicted that the more consumers are satisfied by psychological factors (product quality, variety of products, transportation convenience, parking convenience, atmosphere, and kindness of the merchants), the more they spend in traditional markets. Regarding physical factors, it is anticipated that the time required to get to the traditional market will have a negative $(-)$ influence on consumer behaviors in traditional markets. Retailers are typically location-sensitive. Therefore, it is highly unlikely that consumers would visit traditional markets located long distances away from where they lived. It is also expected that length of residence and average monthly income (which are socioeconomic factors) would have a positive $(+)$ influence on consumer spending in the traditional market. High income means an increase in disposable income. Because an increase in disposable income is a necessary and sufficient condition to increased spending. consumers with high income would spend more in traditional markets. Therefore, the length of residence would likely have a positive $(+)$ influence on the use of traditional markets. Unlike other types of retailers, traditional markets have long-term relationships with the residents in the area. The longer they have lived in the area, the more frequently they would have visited the traditional market. This would naturally increase spending in the traditional market, On the other hand, it is anticipated that the number of cars owned would have a negative (-) influence on consumers using the traditional markets. Consumers who own cars can travel freely and are hence more likely to visit retailers located at a distance than are consumers who do not have cars. Therefore, consumers with cars are highly likely to choose other types of retailers over traditional markets. It is anticipated that the number of cars owned would have a negative (-) influence on consumers using traditional markets. Therefore, consumers with cars are likely to choose other 
types of retailers over traditional markets. $\langle$ Table 1$\rangle$ lists the above variables.

\subsection{Analysis Method}

This research analyzes how spatial competition among traditional markets, large discount stores, and SSMs influences consumer behav- iors in traditional markets. Therefore, we should select a model that uses spatial relation as an analysis method. More sophisticated procedures are necessary to identify the relationship between store sales and the various predictor variables. Using multiple regression analysis, a usable model can be made with predictable and most reasonable predictor variables. Simkin et

$\langle$ Table 1〉 Variables that influence consumer behaviors according to type of distribution business

\begin{tabular}{|c|c|c|c|}
\hline Variables & & Details & Remarks \\
\hline $\begin{array}{l}\text { Dependent } \\
\text { variables }\end{array}$ & \multicolumn{2}{|c|}{$\begin{array}{l}\text { Average monthly spending in traditional } \\
\text { markets }\end{array}$} & Unit: Korean won \\
\hline \multicolumn{4}{|l|}{$\begin{array}{l}\text { Independent } \\
\text { variables }\end{array}$} \\
\hline \multirow{7}{*}{$\begin{array}{l}\text { Psychological } \\
\text { factors }\end{array}$} & \multicolumn{2}{|c|}{ Product price } & \multirow{7}{*}{$\begin{array}{l}\text { Very dissatisfied: } 1 \text { point } \\
\text { Dissatisfied: } 2 \text { points } \\
\text { Average: } 3 \text { points } \\
\text { Satisfied: } 4 \text { points } \\
\text { Very satisfied: } 5 \text { points }\end{array}$} \\
\hline & \multicolumn{2}{|c|}{ Product quality } & \\
\hline & \multicolumn{2}{|c|}{ Variety of products } & \\
\hline & \multicolumn{2}{|c|}{ Transportation convenience } & \\
\hline & \multicolumn{2}{|c|}{ Parking convenience } & \\
\hline & \multicolumn{2}{|r|}{ Atmosphere } & \\
\hline & \multicolumn{2}{|r|}{ Kindness } & \\
\hline Physical factors & \multicolumn{2}{|c|}{ Time required to travel to a traditional market } & Unit: minutes \\
\hline \multirow{6}{*}{$\begin{array}{l}\text { Socioeconomic } \\
\text { factors }\end{array}$} & \multirow{2}{*}{$\begin{array}{c}\text { Number of cars } \\
\text { owned }\end{array}$} & None (referred group) & \\
\hline & & 1 unit or more & \\
\hline & \multicolumn{2}{|c|}{ Average monthly income } & \\
\hline & \multirow{3}{*}{$\begin{array}{l}\text { Length of } \\
\text { residence }\end{array}$} & $\begin{array}{l}2 \text { years or less } \\
\text { (referred group) }\end{array}$ & \\
\hline & & $3 \sim 9$ years & \\
\hline & & 10 years or longer & \\
\hline \multirow{5}{*}{$\begin{array}{l}\text { Competitive } \\
\text { factors }\end{array}$} & \multirow{3}{*}{$\begin{array}{l}\text { Spatial } \\
\text { competition }\end{array}$} & Strong & Seoul Gangseo, Gyeonggi-do Uijeongbu \\
\hline & & Average & Gyeonggi-do Dongducheon, Incheon Seo-gu \\
\hline & & Weak & Incheon Ganghwa, Seoul Gwan'ak-gu \\
\hline & \multirow{2}{*}{$\begin{array}{l}\text { Competition in } \\
\text { consumption } \\
\text { behaviors }\end{array}$} & $\begin{array}{l}\text { Average monthly spending } \\
\text { in large discount stores }\end{array}$ & Unit: Korean won \\
\hline & & $\begin{array}{l}\text { Average monthly spending } \\
\text { in SSMs }\end{array}$ & Unit: Korean won \\
\hline
\end{tabular}


$\langle$ Table 2〉 Formula between dependent variables and independent variables

Average monthly spending in traditional markets $=\mathrm{F}$ (invariable + psychological variables + physical variables + socioeconomic variables + competitive variables)

al. (1985) used this regression model to analyze major grocery retailers. Davies (1973), using this model, obtained a significant result from an analysis of how the five variables (including rent and rates) influenced sales in 72 analogous tailoring stores. This research also estimates the coefficients of the independent variables for the dependent variables through the multiple regression model and the Ordinary Least Square (OLS) method. The average monthly spending in traditional markets is the linear combination of psychological variables, physical variables, socioeconomic variables, and competitive variables. Here, the correlation function means the multiple regression model. The multiple regression analysis uses SAS 9.2.

Before conducting an analysis, it is necessary to check whether multicollinearity, which is likely to occur among the explanatory variables, has been effectively controlled in the model. In order to measure multicollinearity among the independent variables, we use the variance inflation factor (VIF). The VIF values of the independent variables controlled in this research were all less than 5. Accordingly, we can see that the multicollinearity among the independent variables was effectively controlled.

\section{Analysis and results}

\subsection{Data development}

Data for the analysis was obtained through a survey of consumers. The survey was conducted from May 16 through May 21, 2011. The surveyors collected information through one-on-one interviews with consumers in markets, in accordance with the questionnaire. Of the 861 samples collected, 613 were used in the final analysis. According to the region, 110 samples were collected from Gangseo-gu of Seoul, 108 from Gwan'ak-gu of Seoul, 110 from Uijeongbu-si of Gyeonggi-do, 106 from Dongducheon-si of Gyeonggi-do, 69 from Seo-gu of Incheon, and 110 from Ganghwa-kun of Incheon. The characteristics of the samples are as follows:

The percentage of male and female is $20.2 \%$ and $79.8 \%$, respectively. According to age group, $10.6 \%$ are in their $20 \mathrm{~s}, 18.8 \%$ in their 30 s, $30.5 \%$ in their 40 s, $29.0 \%$ in their 50 s, and $11.1 \%$ in their 60 s or older. According to educational background, high-school graduates account for $68.2 \%$, middle-school graduates for $6.2 \%$, and university graduates for over $25.6 \%$. According 
$\langle$ Figure 1〉 Market locations for analysis

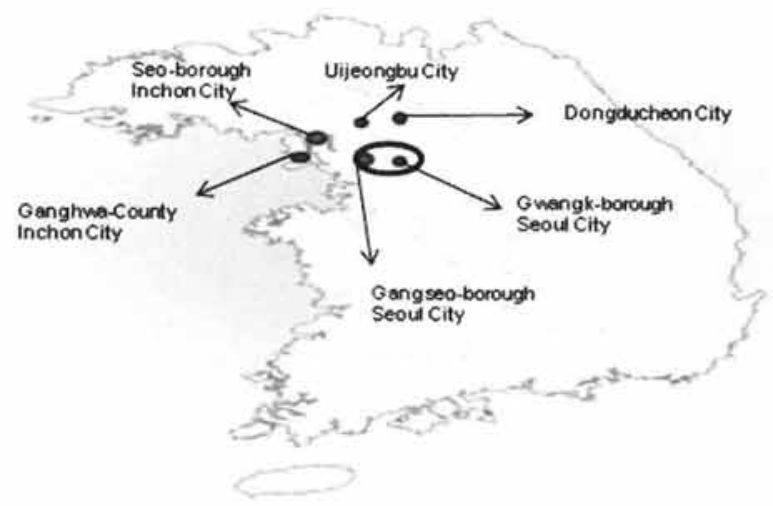

to profession, "other," at the highest, accounts for $48.5 \%$, "service" accounts for $16.4 \%$. "selfemployed" accounts for $15.0 \%$, and "office job" accounts for $12.6 \%$. According to length of residence, people who have resided in the area for longer than 10 years account for $50.1 \%$. According to marital status, $88.1 \%$ are married and $11.9 \%$ are single.

\subsection{Results of the Empirical Analysis}

The number of samples should be examined in depth according to type of competition. The proportion of types of spatial competition among the three businesses is as follows: strong accounts for $36 \%$, average accounts for $29 \%$, and weak accounts for $35 \%$. Among psychological factors, satisfaction with quality of products and product price are the highest in traditional markets: these factors are followed by variety of products and atmosphere of the market.
Parking convenience provides a result of 2.70 , which is the lowest. These results indicate the reality of traditional markets, which is satisfaction with the low prices and high quality of the products sold but low satisfaction with parking convenience because of the scarcity of parking space.

The following table $\langle$ Table 5$\rangle$ shows the results of the regression analysis by applying the least-squares method. In this analysis, Adj $\mathrm{R}-\mathrm{Sq}$ was analyzed as 0.15 . Considering that cross-sectional data was used in the analysis, it is difficult to state that the model has low explanation. Except for the psychological factors, the influence of the independent variables on average monthly spending in traditional markets is expected to be in line with the hypothesis. Among the psychological factor variables, none has high levels of statistical significance. Quality of products, transportation convenience, and parking convenience have 
$\langle$ Table 3$\rangle$ General characteristics of the survey subjects

\begin{tabular}{|c|c|c|c|c|c|c|c|}
\hline Type & Description & $\begin{array}{l}\text { Freq. } \\
\text { (people) }\end{array}$ & $\begin{array}{l}\text { Ratio } \\
(\%)\end{array}$ & Type & Description & $\begin{array}{c}\text { Freq. } \\
\text { (people) }\end{array}$ & $\begin{array}{l}\text { Ratio } \\
(\%)\end{array}$ \\
\hline \multirow{2}{*}{ Gender } & Male & 124 & 20.2 & \multirow{6}{*}{$\begin{array}{l}\text { Length of } \\
\text { residence } \\
\text { (years) }\end{array}$} & 1 year or less & 13 & 2.1 \\
\hline & Female & 489 & 79.8 & & $1 \sim 2$ years & 34 & 5.6 \\
\hline \multirow{5}{*}{ Age } & $20 \mathrm{~s}$ & 65 & 10.6 & & $3 \sim 4$ years & 69 & 11.3 \\
\hline & $30 \mathrm{~s}$ & 115 & 18.8 & & $5 \sim 9$ years & 190 & 31.0 \\
\hline & $40 \mathrm{~s}$ & 187 & 30.5 & & $10 \sim 20$ years & 163 & 26.6 \\
\hline & $50 \mathrm{~s}$ & 178 & 29.0 & & 20 years or more & 144 & 23.5 \\
\hline & 60 s or older & 68 & 11.1 & \multirow{2}{*}{ Marital status } & Married & 540 & 88.1 \\
\hline \multirow{3}{*}{$\begin{array}{l}\text { Educational } \\
\text { background }\end{array}$} & Middle-school graduate & 37 & 6.2 & & Single & 73 & 11.9 \\
\hline & High-school graduate & 410 & 68.2 & \multirow{5}{*}{$\begin{array}{l}\text { Number of } \\
\text { family } \\
\text { members } \\
\text { (persons) }\end{array}$} & 1 & 10 & 1.6 \\
\hline & University graduate & 154 & 25.6 & & 2 & 52 & 8.5 \\
\hline \multirow{12}{*}{ Occupation } & Agriculture & 2 & 0.3 & & 3 & 169 & 27.6 \\
\hline & Self-employed & 92 & 15.0 & & 4 & 361 & 58.9 \\
\hline & Office job & 77 & 12.6 & & 5 or more & 21 & 3.4 \\
\hline & Production worker & 7 & 1.1 & \multirow{3}{*}{$\begin{array}{l}\text { Number of } \\
\text { cars owned } \\
\text { (units) }\end{array}$} & None & 73 & 11.9 \\
\hline & Specialist & 5 & 0.8 & & 1 & 510 & 83.2 \\
\hline & Teacher & 2 & 0.3 & & 2 or more & 30 & 4.9 \\
\hline & Service business & 101 & 16.4 & \multirow{6}{*}{$\begin{array}{c}\text { Average } \\
\text { monthly } \\
\text { income } \\
\text { (Korean won) }\end{array}$} & 1 million or less & 1 & 0.2 \\
\hline & Day laborer & 8 & 1.3 & & 1 mil. $\sim 2$ million & 12 & 2.0 \\
\hline & Public servant & 6 & 1.0 & & 2 mil. $\sim 3$ million & 88 & 14.3 \\
\hline & Student & 12 & 2.0 & & 3 mil. $\sim 4$ million & 213 & 34.7 \\
\hline & Unemployed & 4 & 0.7 & & 4 mil. $\sim 5$ million & 193 & 31.5 \\
\hline & Other & 297 & 48.5 & & 5 million or more & 106 & 17.3 \\
\hline
\end{tabular}

positive $(+)$ influences on average monthly spending in traditional markets: on the other hand, product price, variety of products, atmosphere, and kindness have negative (-) influences. The time required to travel to the traditional market $(-1.0436)$, which is a physical factor, has a negative $(-)$ influence on average monthly spending in traditional markets, at the $1 \%$ level of significance. The anal- ysis results show that traditional markets that are located near residential areas with high population density are more likely to be revived than those that are not. The number of cars owned and average monthly income, which are socioeconomic factors, indicate high levels of statistical significance. The number of cars owned shows -8.1636 at the $99 \%$ level of confidence. This has a negative (-) influence 
$\langle$ Table 4〉 Basic statistics of the variables

\begin{tabular}{|c|c|c|c|c|}
\hline Variables & & Details & Average & Standard deviation \\
\hline Dependent variables & \multicolumn{2}{|c|}{ Average monthly spending in traditional markets } & 92,322 & 206,967 \\
\hline \multicolumn{5}{|l|}{ Independent variables } \\
\hline \multirow{7}{*}{ Psychological factors } & \multicolumn{2}{|r|}{ Product price } & 3.87 & 0.59 \\
\hline & \multicolumn{2}{|r|}{ Product quality } & 3.88 & 0.70 \\
\hline & \multicolumn{2}{|c|}{ Variety of products } & 3.72 & 0.71 \\
\hline & \multicolumn{2}{|c|}{ Transportation convenience } & 3.47 & 0.86 \\
\hline & \multicolumn{2}{|c|}{ Parking convenience } & 2.70 & 0.82 \\
\hline & \multicolumn{2}{|r|}{ Atmosphere } & 3.71 & 0.71 \\
\hline & \multicolumn{2}{|r|}{ Kindness } & 3.54 & 0.60 \\
\hline Physical factors & \multicolumn{2}{|c|}{$\begin{array}{l}\text { Time required to travel to a traditional market } \\
\text { (minutes) }\end{array}$} & 13.76 & 5.60 \\
\hline \multirow{6}{*}{ Socioeconomic factors } & \multirow{2}{*}{$\begin{array}{l}\text { Number of cars } \\
\text { owned }\end{array}$} & None (referred group) & 0.10 & 0.30 \\
\hline & & 1 unit or more & 0.90 & 0.30 \\
\hline & \multicolumn{2}{|c|}{ Average monthly income (won) } & $3,869,494$ & 860,403 \\
\hline & \multirow{3}{*}{$\begin{array}{l}\text { Length of } \\
\text { residence }\end{array}$} & $\begin{array}{l}2 \text { years or less } \\
\text { (referred group) }\end{array}$ & 0.10 & 0.30 \\
\hline & & $3 \sim 9$ years & 0.45 & 0.50 \\
\hline & & 10 years or longer & 0.45 & 0.50 \\
\hline \multirow{5}{*}{ Competitive factors } & \multirow{3}{*}{$\begin{array}{l}\text { Spatial } \\
\text { competition }\end{array}$} & Strong & 0.36 & 0.48 \\
\hline & & Average & 0.29 & 0.45 \\
\hline & & Weak & 0.35 & 0.48 \\
\hline & \multirow{2}{*}{$\begin{array}{l}\text { Competition in } \\
\text { consumption } \\
\text { behaviors }\end{array}$} & $\begin{array}{c}\text { Average monthly spending in } \\
\text { large discount stores }\end{array}$ & 315,157 & 518,818 \\
\hline & & $\begin{array}{l}\text { Average monthly spending in } \\
\text { SSMs }\end{array}$ & 50,108 & 139.536 \\
\hline
\end{tabular}

on the use of traditional markets. Also, average monthly income (-1.3515) has a negative (-) influence on the use of the traditional markets at the $90 \%$ level of confidence. These two variables are income-related variables. Accordingly, high-income households are more likely to use other retailers than traditional markets. The fact that high-income households avoid tradi- tional markets is a negative factor in the revitalization of these markets. Therefore, a strategic policy that can attract high-income households to traditional markets is urgently required. On the other hand, the analysis shows that length of residence, which is a socioeconomic factor, has a positive $(+)$ influence on the use of traditional markets, although the 
〈Table 5〉 Estimated coefficients by variable and level of significance

\begin{tabular}{|c|c|c|c|c|}
\hline \multirow{2}{*}{\multicolumn{2}{|c|}{ Variables }} & \multicolumn{2}{|c|}{ Estimated coefficients } & \multirow[b]{2}{*}{ Standard error } \\
\hline & & $\begin{array}{l}\text { Non-standard } \\
\text { coefficient }\end{array}$ & $\begin{array}{l}\text { Standard } \\
\text { coefficient }\end{array}$ & \\
\hline & Invariable & $46.0273^{* * *}$ & 0.0000 & 7.9505 \\
\hline \multicolumn{5}{|c|}{$\langle$ Psychological factors $\rangle$} \\
\hline & Product price & -1.2736 & -0.0366 & 1.5047 \\
\hline & Product quality & 0.1800 & 0.0061 & 1.4790 \\
\hline & ariety of products & -0.6659 & -0.0228 & 1.3791 \\
\hline Trans & portation convenience & 0.7551 & 0.0313 & 1.1642 \\
\hline & rking convenience & 0.3078 & 0.0122 & 1.0593 \\
\hline & Atmosphere & -0.3323 & -0.0114 & 1.4893 \\
\hline & Kindness & -0.1811 & -0.0053 & 1.4677 \\
\hline \multicolumn{5}{|c|}{$\langle$ Physical factors $\rangle$} \\
\hline Time required & $\begin{array}{l}\text { to get to a traditional market } \\
\text { (minutes) }\end{array}$ & $-1.0436^{* * *}$ & -0.2823 & 0.1521 \\
\hline \multicolumn{5}{|c|}{ 〈Socioeconomic factors〉 } \\
\hline \multicolumn{2}{|c|}{ Number of cars owned } & $-8.1636^{* * *}$ & -0.1179 & 2.9484 \\
\hline \multicolumn{2}{|c|}{ Average monthly income } & $-1.3515^{*}$ & -0.0562 & 1.0582 \\
\hline \multirow{2}{*}{$\begin{array}{l}\text { Length of } \\
\text { residence }\end{array}$} & $3 \sim 9$ years & 0.7344 & 0.0176 & 2.8089 \\
\hline & 10 years or longer & 1.7706 & 0.0425 & 2.9198 \\
\hline \multicolumn{5}{|c|}{$\langle$ Competitive factors $\rangle$} \\
\hline \multirow{2}{*}{ Spatial } & Strong & $-5.8715^{* * *}$ & -0.1359 & 1.8979 \\
\hline & Average & $-8.4850^{* * *}$ & -0.1855 & 2.1295 \\
\hline \multirow{2}{*}{$\begin{array}{l}\text { Consumption } \\
\text { behaviors }\end{array}$} & $\begin{array}{l}\text { Average monthly spending } \\
\text { in large discount stores }\end{array}$ & $-0.3109^{* *}$ & -0.0783 & 0.1570 \\
\hline & $\begin{array}{l}\text { Average monthly spending } \\
\text { in SSM }\end{array}$ & -0.6974 & -0.0473 & 0.5811 \\
\hline
\end{tabular}

Adj R-Sq: 0.15

${ }^{* * *} \mathrm{p}<0.01,{ }^{* *} \mathrm{p}<0.05,{ }^{*} \mathrm{p}<0.1$

level of statistical significance is not as high. Therefore, it can be interpreted that traditional markets were community-centered in the past: recently, however, this aspect of the past has been changing.

Apart from the psychological factors, physical factors, and socioeconomic factors that influ- ence consumers using traditional markets, competitive factors were found to have a negative $(-)$ influence on average monthly spending in traditional markets. According to the analysis, "strong" spatial competition (-5.8715) and "average" spatial competition (-8.4850) among traditional markets, large discount stores, and SSMs have 
a negative (-) influence on average monthly spending in traditional markets. Both variables show a $1 \%$ or higher level of statistical significance. This also indicates that the average monthly spending in large discount stores (-0.3109) and SSMs (-0.6974) is negatively $(-)$ related to average monthly spending in traditional markets. However, the large discount stores and SSMs show a $5 \%$ or higher level of significance, whereas the traditional markets show a low level of statistical significance. This is significant because, through this analysis, we have confirmed that the spatial competition between traditional markets and other types of retailers has a direct influence on the revitalization of traditional markets. In addition, we can see that the competition between traditional markets and large discount stores is a bigger obstacle to the revitalization of traditional markets than is the competition between traditional markets and SSMs. In the model established in this research, the independent variable that most influences average monthly spending in the traditional market is the time required to get to the traditional market $(-0.2823)$. This result proves that the location of retailers, especially traditional markets, is most important. Securing the population residing within the radius of the retailer is necessary for revitalizing the retailer, even for traditional markets. The spatial competition among traditional markets, large discount stores, and SSMs has been shown to influence consumers using traditional markets.
Of the three types of spatial competition, "average" competition $(-0.1855)$ and "strong" competition $(-0.1359)$ are shown to have a greater effect on consumers using traditional markets than no competition. This reminds us of how important the location of the retailer is. In other words, traditional markets that are located in areas with intensified competition between the traditional market and other competing retailers are highly likely to decline. Additionally, the analysis shows that the number of cars owned $(-0.1179)$ has a strong effect on consumers using traditional markets. This variable is an important factor for the traditional markets because it represents level of income and because consumers with cars are more likely to travel longer distances for shopping.

\section{Conclusion and Implications}

Traditional markets encounter difficulties because large discount stores and SSMs are expanding their businesses. In order to revive the regional economy, the Korean government provides tangible and intangible support for these declining traditional markets, which are mostly occupied by small business owners. We carried out an empirical research of the spatial competition among the key players-large discount stores, SSMs, and traditional markets-on the distribution market, from the aspect of location. 
We analyzed how this competition influences consumer behaviors in 6 cities around the Seoul metropolitan area.

We found strong evidence for most of the variables drawn from the theoretical framework. Concretely, the findings from the analysis on how competition among businesses influences consumer behaviors are as follows: There are no variables with high levels of statistical significance among the satisfaction variables (which are psychological factors) of the traditional market. The analysis indicates that the time required to travel to the traditional market (which is a physical factor) and the number of cars owned and average monthly income (which are socioeconomic factors) have a negative (-) influence on consumer behaviors in the traditional market with high levels of statistical significance. The spatial competition among the traditional markets, large discount stores, and SSMs in this analysis shows high levels of statistical significance and has a negative (-) influence on average monthly spending in the traditional market. When analyzing how the independent variables influence consumer behaviors in traditional markets, we found that the time required to travel to the traditional market, spatial competition, income, and number of cars owned have considerably more influence that do other variables on average monthly spending in traditional markets. These results have several political implications. First, the intense spatial competition among the tra- ditional markets, large discount stores, and SSMs directly influences the decline of traditional markets. From the perspective of revitalization, the unsuccessful location management of large discount stores and SSMs by the government has accelerated the decline of traditional markets. Considering the location-oriented characteristics of retailers, the locations of the traditional markets' competitors directly influence the competitiveness of traditional markets. In order to revive these traditional markets, the government should establish an effective policy on the management of the locations of traditional markets and of the retailers that are in competition with these traditional markets. The management of locations should include the selection of reasonable locations for competing retailers considering the intense competition with traditional markets in the distribution industry. The government must manage this policy strategically. Second, we found that the competition between traditional markets and large discount stores has a stronger influence on consumer behaviors in traditional markets than does the competition between traditional markets and SSMs. This can be seen as a natural result of the agglomeration economy of the large discount stores. From the aspect of revitalization of the traditional markets, however, a policy that can ease the intense competition between traditional markets and large discount stores is urgently required. For example, for areas in which large discount stores are located, col- 
laboration between the large discount stores and traditional markets can be a win-win solution to easing the competition. Therefore, the government should establish win-win measures for traditional markets and their competitors. Third, we found that consumers who use traditional markets that are located in regions with intense competition among traditional markets, large discount stores, and SSMs spend less than who use traditional markets in regions with no competition among retailers. This result can be used by the government as the basis for a policy to revive traditional markets. The government should create this policy keeping in mind the distinction between traditional markets located in regions with intense competition and those in regions with no competition. As discussed earlier, a win-win solution for traditional markets and their competitors in such regions is needed in order to revive the traditional markets. Fourth, we found that the time required to travel to the traditional market influences consumer behaviors in traditional markets. The smaller the geographical distance to the traditional market from where the consumer resides, the more likely it is that the consumer will use the traditional market.

This finding indicates that traditional markets that are located in regions with high population density are more likely to be revived under the same conditions. Therefore, when the government establishes a policy for the revitalization of traditional markets, it should consider diverse aspects including location, population density, and number of potential users. Lastly, we found that the high-income class avoids traditional markets. Normally, the market is led by the high-income class. In addition, consumers with strong purchasing power can increase the sales of a retailer in a short period. This can be an effective strategy to revive traditional markets in a short time. From this perspective, the government should create a policy to attract the high-income class to traditional markets in order to revitalize these markets. This research provides policy implications to invigorate traditional markets by analyzing the effect of the competitive sphere among large discount stores, SSMs, and traditional markets on consumption behavior. We propose that the policy supporting traditional markets should be a customized-strategy, considering each traditional market's characteristic. However, it would be impractical to regard the results of the survey conducted in this research as a representation of all consumers who use traditional markets, since the scope of the survey was limited to the metropolitan area and the sample size was only 613. Another limitation of this study is that demographic characteristics could be a critical factor to invigorate consumer-oriented traditional markets by analyzing the consumption behavior. We need to consider further factors such as demographic characteristics that influence on consumer's consumption behavior in intensive competition 
in Korean retail industry. In future research, we need to consider diverse factors such as regulation and marketing strategies for the revitalization of traditional markets as independent variables, which have an influence on consumer behavior.

〈Received February 25. 2013〉

〈Revised March 28. 2013〉

〈Accepted April 2. 2013〉

\section{References}

Alexanderu M. Degeratu., (2000), "Consumer Choice Behavior in Online and Traditional Supermarkets: The Effects of Brand Name, Price, and other Search Attributes," International Journal of Research in Marketing, Vol.17, No.1, PP.55-78.

Bell D.R., Ho T.H., Tang C.S., (1998), "Determinant where to shop: fixed and variable costs of shopping," Journal of Marketing Research, 35, 352-369.

Belsawa, C.S., (1965), Traditional Exchange and Modern Market, Prentice-Hall, Englewood Cliff,N.J.

Blackwell R.D., Miniard P.W., and Engel J.F., (2001), "Consumer Behavior and Marketing Strategy," Harcourt College.

Brennan, D.P., and Lundsten, L., (2000), Impact of large discount stores on small U.S. towns: Reasons for shopping and retailer strategies. International Journal of Retail and Distribution Mangement, 28(4-5). 159. Bucklin L.P.. (1996), "A Theory of Distribution Channel Structure," Institute of Business and Economic Research, Berkley, CA.

Burk, M. C., (1967), Survey of interpretations of consumer behavior by social scientists in the postwar period. Journal of Farm Economics, 49, ppl-31.

Chowdhury J., Reardon J., and Srivastava R., (1998), “Alternative Modes of Measuring Store Image: An Empirical Assessment of Structured versus Unstructured Measures," Journal of Marketing Theory and Practice. 6(2), 72-86.

Chul-Jung Kim, (2008), The study of making discount store focused on the relationship with the customer service quality and repurchase,

Clarke, I., (2000), Retail power, competition and local consumer choice in the UK grocery sector. European Journal of Marketing, 34 (8), 975-1002.

Davis, R.L.. (1973), 'Evaluation of retail store attributes and sales performance', European Journal of Marketing, 7(2), 89-102.

Department for Communities and Local Government in the UK, (2010), Retail Markets: A good practice guide, pp. 1-17.

Do-Hyoung Park, Jumin Lee, Ingoo Han, (2007), The Effect of On-Line Consumer Reviews on Consumer Purchasing Intention: The Moderating Role of Involvement. In- 
ternational Journal of Electronic Commerce, Volume 11, Number 4/Summer 2007, pp. 125-148.

E. M. Tauber, (1972), "Marketing Notes and Communication: Why Do People Shop?." Journal of Marketing, vol. 36, no. 4, 1972. Oct, pp. 46-49.

Farina, E. M.M.Q., Nunes, R. and Monteiro, G.F.D.A.. (2005), Supermarkets and their impacts on the agrifood system of Brazil: The competition among retailers. Agribusiness, Volume21, Issue2, pages. 133-147(doi/10.1002 /agr.v21:2/issuetoc).

Gripsrud G., and Horverak, (1998), "Determinants of retail patronage: a 'natural' experiment," International Journal of Research in Marketing, 3, 263-272.

Goodchild, M.F., (1991), 'Geographic information systems', Journal of Retailing, 67(1). 3-15. Goldman A, Hino H, (2005), Supermarkets vs. traditional retail stores: diagnosing the barriers to supermarkets market share growth in an ethnic minority community. J. Retail. Consum. Serv., 12(4) : 273-284. Ibrahim MF and Leng SK, (2003), Shoppers perceptions of retail developments: Suburban shopping centres and night markets in Singapore. J. Retail Leis. Prop., 3(2) : 176189.

Jai Ok Kim and Byoungho Jin, (2001), Korean consumers' patronage of discount stores: domestic vs multinational discount store shoppers' profiles, Journal of Consumer
Marketing. Vol. 18 Iss:3, pp.236-255.

J.F.Engel and R.D.Blackwell, (1982), “Consumer Behavior". New York: The Dryden Press. Kathleen Cleeren, Frank Verboven, Marnik G. Dekimpe and Katrijn Gielens, (2010), Intraand Interformat Competition Among Discounters and Supermarkets, Marketing Science, Vol.29. No.3.456-473.

Kim, C. D., (2005), A Study for Revitalizing Local Markets After Operating SurroundingsImprovement Project. Seoul Development Institute.

Kim, S. B., Yong, H. J., Yoo, J. G., \& Kim, D. Y.(2000) Revitalization of Traditional Markets in Jinju. Journal of Global Academy of Marketing Science, 6(0), p. 26.

Levy M., and Weitz B.. (2001), "Retailing Management," McGraw-Hill/Irwin.

Liand, T.P. \& Huang, J.S., (1998), An empirical study on consumer acceptance of products in electronic markets: a transaction cost model. Decision Support Systems, 24, 29-43.

M. Adam Mahmood, Kallol Bagchi, Timothy C. Ford, (2004), On-line Shopping Behavior: Cross-Country Empirical Research, International Journal of Electronic Commerce, Volume9, Number 1, pages:9-30.

Marios Koufaris, (2002), Applying the Technology Acceptance Model and Flow Theory to Online Consumer Behavior, Information Systems Research, Vol.13, No. 2, June 2002, pp. 205-223. 
Nobel, S.T., Griffith, D. A.. and Adjei, M.T., (2006). Drivers of local merchant loyalty: Understanding the influence of gender and shopping motives. Journal of Retailing, 82(3), pp. 184-185.

Ricardo Hernandez, Thomas Reardon, Julio Berdegue, (2006), Supermarkets, wholesalers, and tomato growers in Guatemala, Agricultural Economics, 36(2007), 281-290.

Rick L. Andrews and Imran S. Currim, (2004), Behavioural differences between consumers attracted to shopping online versus traditional supermarkets: implications for enterprise design and marketing strategy. Int. $J$. Internet Marketing and Advertising. Vol. 1, No. 1. pp. 38-61.

Rynyon KE, (1980), Consumer behavior and the practice of marketing (Second ed.) Columbus: Charles E. Merrill Publishing Company.

Sangwoo Lee, Chunjie Xiao, Shengji Pei, (2008), Ethnobotanical survey of medical plants at periodic markets of Honghe Prefecture in Yunnan Province, SW. China, Journal of Ethnopharmacology, 117, pp.362-377.

Simkin, L.P.. P. Doyle and J. Saunders, (1985), 'How retailers put site location techniques into operation', Retail \& Distribution Management, 13(3), 21-26.
Sheri L. Lokken, Ginger Wigington Cross, Linda K. Halbert, Gail Lindsey. Christy and Carla Stanford, (2003), Comparing online and nononline shoppers, international journal of consumer studies, 27, 2, March, 2003, pp. 126-133.

Schiffman, L. and Kanuk, L., (1987), Consumer Behavior. New Jersey: Prentice-Hall.

Vishal P. Singh and Karsten T. Hansen, Robert C. Blattberg., (2006), Market Entry and Consumer Behavior: An Investigation of a Wal-Mart Supercenter, Marketing Science, Vol. 25. No. 5, September-October 2006, pp. 457-476.

Woohyoung Kim and Alan G. Hallsworth, (2013), Large format stores and the introduction of new regulatory controls in South Korea, The International Review of Retail, Distribution and Consumer Research, 21 Jan 2013, DOI: 10.1080/09593969.2012.754779. Woohyoug Kim and Hyun Kim, (2012), Regional Development Strategy for Increasing Cultural Tourism Business in South Korea, Asia Pacific Journal of Tourism Research, DOI:10.1080/10941665.2012.695285.

Small \& Medium Business Administration, (2010), Comprehensive plans for the revitalization of the traditional markets (www: smba.go.kr) 


\title{
유통업태간 경쟁구도가 소비행태에 미치는 영향에 관한 실증연구
}

\author{
이 수 동* \\ 김 우 형**
}

\section{요 약}

본 연구의 목적은 유통업태 간 경쟁이 격화되고 있는 시점에서 주요 유통업태 간 소비행태 분석을 통해 소비자 지향의 전통시장 활성화 정책을 제시하는데 있다. 주요 유통업태 간 공간적 경쟁구도가 소비행태에 미치는 영향을 알아보기 위해 다중회귀분석을 이용하여 전국 6 개 도시에 거주하는 613 명 의 소비자를 대상으로 실증분석 하였다. 본 논문은 크게 3 개의 요소들이 소비행태에 영향을 미치는 것 을 확인하였다. 분석 결과 물리적 요인(전통시장까지 소요시간), 사회경제적요인(승용차 보유대수, 월 평균 소득), 경쟁적 요인(공간적 경쟁구도의 강함과 중간, 대형마트 월평균 지출액)이 소비행태에 유 의한 영향을 미치는 것으로 분석되었다. 이러한 결과를 바탕으로 정부는 고객들의 소비행태에 영향을 미치는 요소들을 선별적으로 고려하여 전통시장 활성화 정책을 추진 할 필요가 있다.

핵심개념: 다중회귀분석, 소비행태. 대형마트, 기업형 슈퍼마켓, 유통산업

* 국민대 경영학과 교수(kulsd@ $@ k o o k m i n . a c . k r)$

** 중소기업청 시장경영진홍원 선임연구원(kimwh@sijang.or.kr) 